\title{
V. Observations on the bodily conformation and mental capacity of the negroes
}

\section{Professor Blumenbach}

To cite this article: Professor Blumenbach (1799) V. Observations on the bodily conformation and mental capacity of the negroes, Philosophical Magazine Series 1, 3:10, 141-147, DOI: $10.1080 / 14786449908676972$

To link to this article: http://dx.doi.org/10.1080/14786449908676972

曲 Published online: 18 May 2009.

Submit your article to this journal $\lceil\pi$

Џll Article views: 3

Q View related articles $\square$ 
downwards. He was thirty-five inches high at his birth, and is now thirty-nine; fo that he has grown four inches in nearly as many months. Elephants are always meafured at the fhoulder; for the arch or curve of the back, of young ones particularly, is confiderably higher than any other part, and it is a fure fign of old age whenever this curve is found flattened or confiderably depreffed, after an elephant has once attained his full growth.

Though thefe remarks, as well as feveral others in the above relation, do not come within the plan I propofed, which was merely to defcribe the method of taking wild elephants in the province of Tipura, yet $I$ hope they will not be deemed impertinent or fuperfluous, efpecially as feveral of them tend to eftablifh fome important facts in the natural hiftory of this animal, that are not known, or not attended to, at leaft in any accounts that $I$ had an opportunity of feeing.

V. Obfervations on.tbe bodily Conformation and mental Capacity of the Negroes. By Profeffor BLU MNBACH. Front Magazin für das neuefte aus der Phyfik, Vol. $I V$.

D URING a tour which I made through Swifferland, I faw in the picture-gallery at Pommersfeld four negro heads by Vandyk, two of which in particular had the lines of the face fo regular that the features feemed very little different from the European. At that time, as I had never had an opportunity of acquiring a proper knowledge refpecting the form of the negro head and cranium, by fudying nature, and as $\mathrm{I}$ remembered that $\mathrm{Mr}$. Camper, in a differtation read in the Academy of Painting at Amfterdam, had mentioned that the greater part of the moft eminent painters, and efpecially Rubens, Vandyk and Jordaens, when they painted Moors, copied from Europeans, whofe faces had been blackened for that purpofe, I aicribed the European look of the above 
above negro heads to this common fault. Some month after, however, I had an opportunity of convincing myfelf that there are real negroes whofe features correfpond very nearly with thofe of the Europeans, and that the above heads in the gallery of Pommersfeld might be a true reprefentation of nature.

Going to pay a vifit at Yverdun to the two brothers Treytorrens, one of whom, the chevalier, had been thirty-five years in the French fervice, particularly at St. Domingo; and the other, by means of the opportunities which his brother enjoyed, had a collection of natural curiofities that contained many rare articles, when I entered the court of their elegant habitation, which is fituated on the road to Goumoens, I faw no perfon to hew meinto the houfe, except a woman of an agreeable figure, who was ftanding with her back towards me. When the turned round to give me an anfwer, I was much furprifed to find that the was a female negro, whofe face perfectly correfponded with her figure, and fully juftified the fidelity of likenefs in Vandyk's negro heads, which I had feen at Pommersfeld. All the features of her face, even the nofe and lips, the latter of which were a little thick, though not fo as to be difagreeable, had they been covered with a white fkin, muft have excited univerfal admiration. At the fame time the was not only exceedingly lively, and poffeffed a found underftanding; but, as I afterwards learned, was extremely well informed. and expert in the obftetric art. The handfome pretty negrefs of Yverdun is celebrated far and near as the beft midwife in the Italian part of Swifferland. I was informed by her matter, the chevalier, who has in his fervice alfo a negro man as elegantly formed as a ftatue, that the was a creole from St. Domingo; that both her parents were natives of Congo, but not fo black as the negroes of Senegal.

Since that period I have had an opportunity of feeing and converfing with many negroes, and have procured for my collection a great many anatomical preparations from negro 
bodies, which, together with what I have read in different voyages, tend more and more to convince me of the truth of the two following propofitions :

₹. That between one negro and another there is as much (if not more) difference in the colour, and particularly in the lineaments of the face, as between many real negroes, and other varieties of the human fpecies.

2. That the negroes, in regard to their mental faculties and capacity, are not inferior to the reft of the human race.

The three negro fkulls, which I have now before me, afford, by the very friking gradation with which the lineaments pais from the one to the other, a very evident proof of the firft propofition. One of them, which Mr. Michaelis was fo good as to bring me from New-York, and of which I have given an accurate defeription in another place *, is diftinguifhed by fuch a projecting upper jaw-bone, that, if the fame peculiarity belonged to all negroes, one might be tempted to fuppofe that they had another firft parent than Adam. On the other hand, the lineaments of the third have fo little of the exotic form, and are fo different from the firt, that if I had not diffected the whole head perfectly entire, and juft as it was' when cut from the body, I fhould be in doubt whether I ought to confider it ás having actually belonged to a real negro. The fecond holds a mean rank between both, and in its whole form has a great likenefs to the head of the Abyffinian Abhas Gregorius, a good engraving of which by Heifs, in $169 \mathrm{I}$, from a painting by. Von Sand, I have now before me, and which not only proves in general the clofe affinity of the Abyffinians with the negroes, but approaches much nearer to the ugly negroes, to fpeak according to the European ideas of beauty, than the well-formed negrefs of Yverdun, or the handfome young negro whofe head I diffected as before mentioned, or than a thonfand others whofe features are little different from thofe of the Europeans. What $\mathrm{I}$ have here faid is indeed nothing elfe than a confirmation of a truth long tin my Ofteology, p. 8\%。 
known, which has been already remarked by unprejudicea travellers, as will appear by the following quotations. Lo Maire, in his Voyage to Cape Verd, Senegal, and Gambia*, fays: "Blacknefs excepted, there are female negroes as' well made as our ladies in Europe." Leguat, in his wellknown Voyages $t$, tells us, that he found at Batavia feveral very pretty negreffes, whofe faces had the perfect European form. Adanfon, in his Account of Senegal $\ddagger$, fpeaking of the female negroes there, has the following paffage: "The women are almoft as tall as the men, and equally well made. Their fkin is remarkably fine and foft :-their eyes are black and open; the mouth and lips fmall, and the features are well proportioned. Some of them are perfect beauties. They are exceedingly lively, and have an eafy, free air, that is highly agreeable." Ulloa, in his Noticias Americanas 1, obferves, that fome of the negroes have thick projecting lips, a flat nofe, eyes deeply funk in the fockets, which in general are called getudos, and wool inftead of hair. He then adds: "Others, whofe colour is equally black, have features perfectly like thofe of the whites, particularly in regard to the nofe and the eyes, and fmooth but thick hair $\S . "$

* Voyages aux Cap Verd, Senegal et Gambie, p. 161.

+ Vol. ii. p. 136 .

+ Page 22 .

II Page 92.

$\$$ The following obfervations of an intelligent Danifh travellermay ferve ftill farther to confirm the truth of Profeffor Blumenbach's propofition: "Almoft all the negroes are of a good ftature, and the Akra negroes have remarkably fine features. The contour of the face, indeed, among the gem nerality of thefe people, is different from that of the Europeans; but at the fame time faces are found among them which, excepting the black colour, would in Europe be confidered as beautiful. In common, how ever, they have fomething apilh. The check-bones and chin project very much; and the bones of the nofe are fmaller than among the Europeans This laft circumftance has probably given rife to the affertion, that the negro women flatten the nofes of their children as foon as they are born. But nofes may be feen among fome of them as much elevated and as regular as thofe of the Europeans. Their hair is woolly, curled and black, but fometimes red. When continually, combed, it may be brought to the length of half a yard; but it never can be kept fmooth. See P. E. Ifert Reis na Guinea, Dordrecht 1790. p. 175. EDIT. 
The teftimonies and examples which ferve to prove the truth of the fecond propofition, refpecting the mental faculties, natural talents and ingenuity of the negroes, are equally numerous and incontrovertible. Their aftonifhing memories, their great activity, and their acutenefs in trade, particularly with gold duft, againft which the moft experienced European merchant cannot be too much on his guard, are all circumftances fo well known, that it. is not neceffary to enlarge on them*. The great aptitude of the flaves for learning every kind of nice handicraft is equally well known; and the cafe is the fame in regard to their mufical talents, as we have inftances of negroes playing the violin in fo mafverly a manner, that they gained fo much money as enabled them to purchafe their liberty $t$.

Of the poetical genius of the negroes inftances are known among both fexes. A female negro, who was a poetefs, is mentioned by Haller ; and a fpecimen of the Latin Poetry of Francis Williams, a negro, may be found in the Hiftory of Jamaica. The interefting letters of Ignatius Sancho, a negro, are well known; and the two following inftances will ferve as a farther proof of the capacity and talents of our black brethren, in regard to literature and fcience. The proteftant clergyman J. J. Eliza Capitein was a negro; a man of confiderable learning, and a great orator. I have in my poffefion an excellent print of him engraved by Tanjé, after P. Vandyk. Our worthy profeffor Hollman, when he was at Wittenberg, conferred the degree of Dostor of Phi-

Barbot, in his Deferiytion of the Coafs of North and South Guinca, to be found in the fifth volume of Churchhill's Collection, relates many interefting things on this fubject. Thus he fays, p. 235. "The blacks are for the moft part men wf fenfe and wit enough, of a harp ready apprchenfion, and an excellent memory beyond what is eafy to imagine; for, though they can neither read nor write, they are always regular in the greatent hurry of bufinefs and trade, and feldom in confufion."

t. Sce Urlfperger's Americanifch Ackerwerk Gottes, p. 3 II.

VoI. III.

I.

lofophy 
lofophy on a negro who had thewn himfelf to advantage, not only as a writer, but as a teacher, and who afterwards came to Berlin as a counfellor of ftate to his Pruffian majefty. I have now before me two treatifes written by him*, one of which, in particular, difplays extenfive and well-digefted reading of the beft phyfiological works of the time. Of the uncommon knowledge which many negroes have had in the practice of medicine, very favourable teftimony has been given by Boerhaave and De Haen, who were certainly competent judges; and the found fkill and delicate expertnefs of the Yverdun accoucheufe are, as already faid, celebrated throughout the whole neighbourhood.

To conclude, the Academy of Sciences at Paris had among the number of its correfpondents M. Liflet a negro, in the the of France, who excelled in making accurate meteorolo-

* One of them is entitled: Difert. inaug. philofopbica de bumance mentis artiosta, frve fenfionis ac facultatis in mente bumana abjentia, et earum in corpore noftro organico ac vivo prefentia, quam Præ. $D$. Mart. Gotth. Loeschero publicè defendit aulior Ant. Guil. Amo, Guinea-Afer, Phil. et A.A. L.L, Mag. et J. V. C. Witteberge $1734, \mathrm{~m}$. Apr. The titie of the other is: Di/p. pbilofopica, continens idean diffindtam corum ques competunt vel menti vel corpori noftro viwo et organico, quam Prafide M. ANT. Gurl. Amo, Guinea-Afro, d: 29. Maii 1734, defendit Jo. THEODos, Meiner Rochliz-Mínie. Philor. et J.V. Cultor. In an account of Amo's life, printed on this occafion in name of the Academic Council, it is faid, among other things refpecting his talents: "Honorem, meritis ingenii partum, infogni probitatis, induftriæ, eruditionis, quam publicis privatifque exercitationibus declaravit, laude auxit-Compluribus philofophiam domi tradidit excuffis tam vete. rum, quam novorum, placitis, optima quaque felegit, feledta enucleate ac dilucide irsterpretatus eft." And the prefident, in defending the firft mentioned treatife, fays exprefsly, in the annexed congratulation to Amo, " Tuum potifimum eminetingenium felicifimum - utpote qui iftius felicitatem ac præftantiam, eruditionis ac dodtrinz foliditatem ac elegantiam, multis fpeciminibus hactenus in noftra etiam academia magno cum applaufu omnibus bonis, et in præfenti differtatione egregiè comprobafti. Reddo tibi illam proprio marte eleganter ac eruditè elaboratam, integram adhuc et plane immutatam, ut vis ingenii tui eo magis exinde elucefcat. 
gical abfervations. On the other hand, whole provinces of Europe might, in my opinion, be named, from which it would be difficult to produce at prefent virtuofo's, poets, philofophers, and correfpondents of a learned academy.

VI. Agenda, or a Collection of Obfervations and Refearcbes the Refults of aubich may ferve as the Fourdation for $a$ Theory of the Earth. By M. DE SAUssure. From Journal des Mines. No. $X X$.

[Continued from page $4 \mathrm{r} \cdot$ ]

C H A P. VI.

Obfervations to be made on Rivers and otber Currents of Water.

1. HXTENT of their courfe, and their inclination from their fources to their mouth.

2. Their dimenfions, breadth, depth and velocity in the different parts of their courfe.

3. Quantity of their periodical increafe and decreafe at different feafons; their temperature during thefe feafons; and the caufes of thefe variations.

4. Limits and caufes of their extraordinary inundations:

5. Whether they are navigable, and to what diftance from their mouth?

6. The nature; purity, and falubrity of their waters.

7. The nature of the fand or mud which they carry along with them; and to what diftance they may be traced on the banks or at the bottom of the fea where their mouths are fituated. M. Beffon even withes that the traveller fhould be furnighed with a wooden veffel (Sebille) to wafh the fand and feparate the more ponderous particles, which may confift of metal or precious ftones. The motion of the waves is alfo 